\title{
The water absorption of Crimean limestone treated with silicic acid based material
}

\author{
Elena Korneeva $^{1 *}$, and Sabri Mohanad Muayad Sabri ${ }^{2}$ \\ ${ }^{1}$ Saint Petersburg State University of Architecture and Civil Engineering, Vtoraja \\ Krasnoarmejskaja 4, St. Petersburg, 190005, Russian Federation \\ ${ }^{2}$ Peter the Great St. Petersburg Polytechnic University, Polytechnicheskaya 29, St. \\ Petersburg, 195251, Russian Federation
}

\begin{abstract}
The paper describes strengthening historical buildings made of limestones rocks located in the Republic of Crimea. The stones were treated with the chemical compound Oxal NK100 for filling a porous material reducing water absorption and strengthening the treated stones. The stones with additives was tested and the results were compared to natural limestones (reference samples) which not treated with any chemicals compounds. All samples are extracted in-site from an actual historical construction located in the mentioned Republic. The effect of the chemical composition Oxal NK100 on the water absorption of the investigated stones is illustrated and incorporated. The comparison data of the index graphs before and after the addition of the chemical composition are given and described.
\end{abstract}

\section{Introduction}

Depending on topography and conditions of formation, limestones are divided into different types. The most famous type is the limestone shell rock, however, besides this type, there are other types so-called mshankovy limestone, marbled limestone, nummulite limestone. Part nummulite limestone includes extinct unicellular organisms nummulites, which belong to Squad foraminifera. The deposits of these types of limestones are located in the Republic of Crimea and are developed mainly on wall materials; only a small amount is used for the production of tiles. Some types of nummulite limestone are very durable, as protected by good preservation. Some of the Egyptian pyramids are made of this kind of stones. Several historical constructions are built mainly from limestones in the Republic of Crimea. Thereby, the question of improving performance characteristics of this type of stones raises. The authors of most scientific papers consider problems such as improving the properties of materials with the help of various additives [1-10]. Also, many scientists are concerned about issues related to the decrease in the strength of materials under the influence of moisture [1119]. Crimean limestone stones have a water absorption ranging from 4 to $30 \%$ with an absolute value of this indicator in the range from 10 to $20 \%$. These numbers indicate that limestone as a porous material.

\footnotetext{
*Corresponding author: linka360639020@yandex.ru
} 
Nevertheless, besides the environmental issues, the destruction of the limestones usually occurs under the impact of various factors [20] such as the negative impact of the water ingress into the pores, mechanical impacts, frosty and chemical issues. These issues leading to material softens and in consequence, the stones considerably lose their performance [2223].

When restoring existing buildings, without demolishing structures, the impregnation methods of possible stone reinforcement compounds must be considered for increasing the operational characteristics of the material.

\section{Methods}

A laboratory study was conducted in order to investigate the water absorption index. The stones were subjected to different types of tests which necessary to figure out how the composition of Oxal NK100 affects the porosity of the material to obtain the effect of the additives on the limestones. Thus, the average density of both series of stones (without a stone-strengthening composition and samples impregnated with Oxal NK100) obtained in the laboratory according to Russian normative documents [21].

The average density $\rho \circ, \mathrm{g} / \mathrm{cm} 3$ is calculated by the formula:

$$
\rho_{0}=\frac{m}{V}
$$

Where: $m$ - mass of the sample, $\mathrm{g}$;

$V$ - sample volume, $\mathrm{cm}^{3}$.

The average density of the stones is calculated by determining the average density of five samples.

The true density $\rho, \mathrm{g} / \mathrm{cm}^{3}$, is calculated by the formula:

$$
\rho=\frac{m-m_{1}}{V}
$$

where $\mathrm{m}$ - mass of the dried sample, $\mathrm{g}$;

$m_{l}-$ mass of the remainder of the sample, $\mathrm{g}$;

$V$ - volume of water displaced by the powder, equal to $20 \mathrm{~cm}^{3}$.

Five parallel tests were repeated to ensure the accuracy of the results. The porosity of the stones is determined based on the previously gained values of the true and average density of the stones.

Porosity $\mathrm{V}_{\mathrm{por}}, \%$, is calculated by the formula:

$$
V V_{\text {por }}=\left(1-\frac{\rho_{0}}{\rho}\right) \cdot 100
$$

Where: $\rho_{\mathrm{o}}$ - average density, $\mathrm{g} / \mathrm{cm}^{3}$

$\rho$ - true density, $\mathrm{g} / \mathrm{cm}^{3}$.

Then, the water absorption of the investigated stones is determined by comparing the mass of the saturated samples to the samples after drying.

Water absorption Wabsorbtion, \% by weight, is calculated by the formula:

$$
W_{\text {absorbtion }}=\frac{m_{1}-m}{m} \cdot 100,
$$

Where: $m_{1}$ - mass of the sample in a state of saturation with water, $\mathrm{kg}$;

$m$ - sample weight in a dry state, $\mathrm{kg}$.

The water absorption is calculated as the arithmetic average of the results of determining the water absorption of five stones samples. 


\section{Results and Discussion}

The average density of limestone samples:

$$
\rho_{0}=\frac{\rho_{01}+\rho_{02}+\rho_{03}+\rho_{04}+\rho_{05}}{5}=\frac{2,156+1,932+2,073+2,011+1,822}{5}=1,999 \mathrm{~g} / \mathrm{cm}^{3} .
$$

The average density of limestone samples NK100:

Natural limestones real density:

$$
\rho_{0}=\frac{\rho_{01}+\rho_{02}+\rho_{03}+\rho_{04}+\rho_{05}}{5}=\frac{2,019+2,093+2,004+1,930+1,922}{5}=1,994 \mathrm{~g} / \mathrm{cm}^{3} .
$$

$\rho=\frac{\rho_{1}+\rho_{2}+\rho_{3}+\rho_{4}+\rho_{5}}{5}=\frac{2,681+2,748+2,774+2,798+2,668}{5}=2,734 \mathrm{~g} / \mathrm{cm} 3$

The limestones (with after the additives of NK100) density:

$\rho=\frac{\rho_{1}+\rho_{2}+\rho_{3}+\rho_{4}+\rho_{5}}{5}=\frac{2,717+2,635+2,561+2,600+2,628}{5}=2,628 \mathrm{~g} / \mathrm{cm} 3$

Limestones Porosity:

$$
\text { Vpor }=\left(1-\frac{\rho_{0}}{\rho}\right) \cdot 100=\left(1-\frac{1,999}{2,734}\right) \cdot 100=26,89 \%
$$

Limestone Porosity NK100:

$$
\text { Vpor }=\left(1-\frac{\rho_{0}}{\rho}\right) \cdot 100=\left(1-\frac{1,994}{2,628}\right) \cdot 100=24,125 \%
$$

\section{Masses of limestone samples, $\mathbf{g}$}

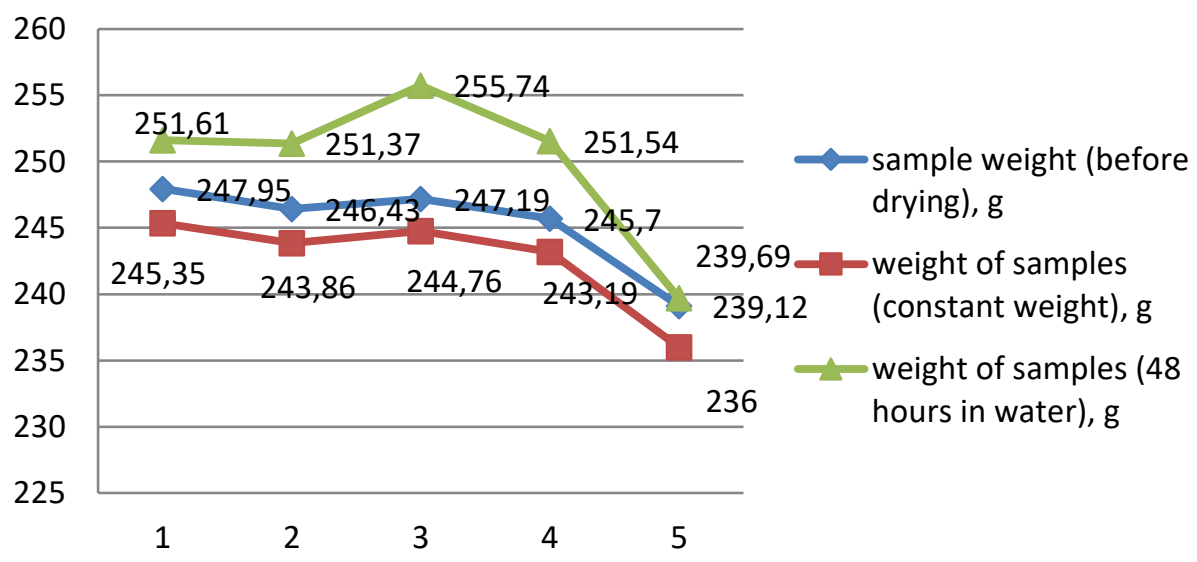

\section{Water absorption}

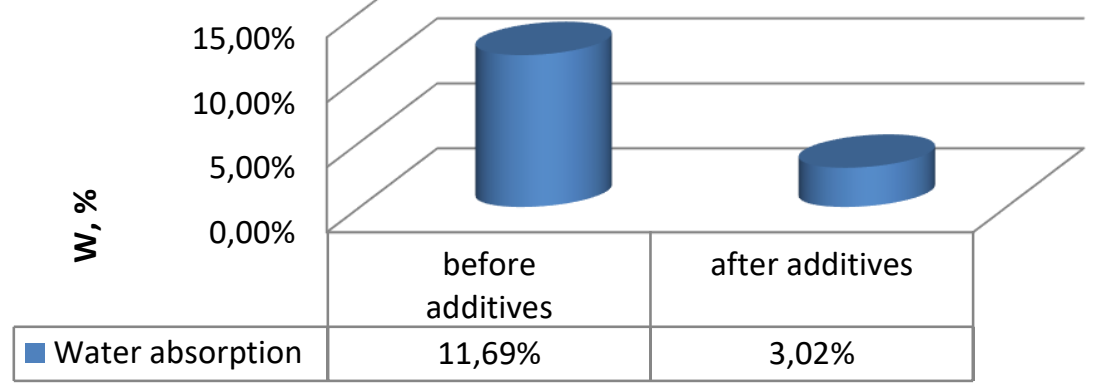




\section{Conclusions}

As a result of this study, it is clear that the porosity of limestones treated with Oxal NK100 is only slightly reduced compared to samples of limestone not treated with a stonestrengthening material, by only $2.73 \%$. However, the water absorption of the natural limestone (reference samples) without treatment is $11.69 \%$, while the water absorption of the treated samples is reduced to $3,023 \%$ which proves the improvement of the stones water absorption after the additive of the composition Oxal Nk100. Thereby, the limestones with the chemical additives (Oxal NK 100) strengthen than the natural limestones (reference samples) as the water absorption of the stones influences different limestones operational properties such the strength and the durability of the investigated stones.

\section{References}

1. I.A. Massalimov, Chuykin A.E., B.I. Massalimov, F.H. Urakaev, B.M. Uralbekov, M.M. Burkitbaev, Nanotechnologies in Construction, 9 (3), 66-80 (2017)

2. M.R. Yanahmetov, A.E. Chuykin, I.A. Massalimov, Nanotechnologies in Construction, 7 (1), 63-72 (2015)

3. D.V. Kurlapov, A.S. Kuvayev, A.V. Rodionov, R.M. Valeyev, Usileniye zhelezobetonnykh konstruktsiy s primeneniyem polimernykh kompozitov [Injection as a method of strengthening stone structures]. Mag. Civ. Eng., 3 (5), 22-24 (2009)

4. V.Yu. Chukhlanov, A.N. Alekseenko, Stroitel'nye materialy, 12, 38-39 (2003)

5. I.A. Massalimov, A.N. Volgushev, A.E. Chuikin, A.N. Khusainov, A.G. Mustafin, Nanotechnologies in Construction, 1, 45-58 (2010)

6. W. Zhang, Q. Sun, S. Zhu, B. Wang, Appl. Therm. Eng., 110, 356-362 (2017)

7. P. Cardiano, R.C. Ponterio, S. Sergi, S. Lo Schiavo, P. Piraino, Epoxy-silica polymers as stone conservation materials. Polymer, 46 (6), 1857-1864 (2005)

8. I.A. Massalimov, M.R. Yanahmetov, A.E. Chuykin, Nanotechnologies in Construction, 7 (3), 61-75 (2015)

9. I. Smirnov, Y. Petrov, G. Volkov, A. Abramian, S. Verichev, A. Bragov, A. Konstantinov, D. Lamzin, Proc. Mater. Sci., 3, 778-783 (2014)

10. Yu.V. Petrov, I.V. Smirnov, G.A. Volkov, A.K. Abramian, A.M. Bragov, S.N. Verichev, J. Rock Mech. Geotech. Eng., 9 (1), 125-134 (2017)

11. T. Parent, N. Domede, A. Sellier, L. Mouatt, Int. J. Rock Mech. Min., 79, 149-156 (2015)

12. Yu.V. Litvinova, Urban Construction and Architecture, 7 (2), 48-52 (2017)

13. E.N. Borodin, A.K. Abramyan, Computational Continuum Mechanics, 10, 341-350 (2017)

14. I.Ya. Kiselyov, Construction materials, the equipment, technologies of XXI century, 8 (187), 34-35 (2014)

15. R.A. Nazirov, S.V. Verkhovets, I.S. Inzhutov, R.V. Bazhenov, I.V. Tarasov, Mag. Civ. Eng., 8, 26-36 (2016)

16. O.V. Tretiakova, Normal stresses of frost heaving as function of excess moisture. Mag. Civ. Eng. 8, 130-139 (2017)

17. D.A. Vakulenko, R.A. Turusov, Mag. Civ. Eng., 7, 106-113 (2017)

18. M. Shepotilo, LesPromInform, 3 (101), 20-24 (2014)

19. O.A. Kiseleva, E.A. Gruzdeva, D.S. Belyakova, Bezopasnost' stroitel'nogo fonda Rossii: materialy mezhdunarodnykh akademicheskikh chteniy RAASN, 242-247 (Kursk, 2011)

20. L. Belec, T.H. Nguyen, D.L. Nguyen, J.F. Chailan, Compos. Part A. 68, 1-235 (2015) 
21. GOST 30629-2011 «Materials and products facing of rocks. Test Method»

22. Alexander B., Vladislav B., Journal of Physical Education and Sport (2016)

23. A.V. Tokareva, O.V. Mironova, I.S. Moskalenko, A.E. Bolotin, L.V. Yarchikovskaya, Teoriya i Praktika Fizicheskoy Kultury (2016) 